\title{
Preventive Behaviors Conveyed on YouTube to Mitigate Transmission of COVID-19: Cross-Sectional Study
}

Corey H Basch ${ }^{1}$, EdD, MPH; Grace C Hillyer ${ }^{2}$, EdD, MPH; Zoe C Meleo-Erwin ${ }^{1}$, PhD, MA; Christie Jaime ${ }^{1}$, MS; Jan Mohlman ${ }^{1}, \mathrm{PhD}$; Charles E Basch ${ }^{3}, \mathrm{PhD}$

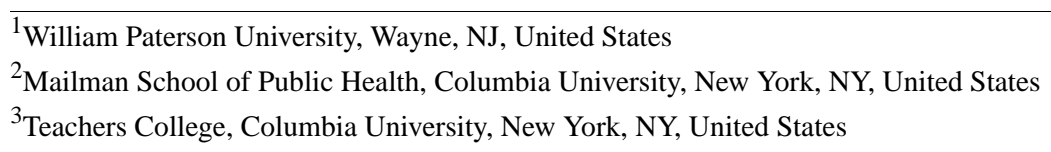

\section{Corresponding Author:}

Corey H Basch, EdD, MPH

William Paterson University

University Hall

Wayne, NJ, 07470

United States

Phone: 19737202603

Email: baschc@wpunj.edu

\section{Related Article:}

This is a corrected version. See correction statement in: https://publichealth.jmir.org/2020/2/e19601/

\section{Abstract}

Background: Accurate information and guidance about personal behaviors that can reduce exposure to severe acute respiratory syndrome coronavirus 2 are among the most important elements in mitigating the spread of coronavirus disease 2019 (COVID-19). With over 2 billion users, YouTube is a media channel that millions turn to when seeking information.

Objective: At the time of this study, there were no published studies investigating the content of YouTube videos related to COVID-19. This study aims to address this gap in the current knowledge.

Methods: The 100 most widely viewed YouTube videos uploaded throughout the month of January 2020 were reviewed and the content covered was described. Collectively, these videos were viewed over 125 million times.

Results: Fewer than one-third of the videos covered any of the seven key prevention behaviors listed on the US Centers for Disease Control and Prevention website.

Conclusions: These results represent an important missed opportunity for disease prevention.

(JMIR Public Health Surveill 2020;6(2):e18807) doi: 10.2196/18807

\section{KEYWORDS}

YouTube; COVID-19; social media; pandemic; outbreak; infectious disease; public health; prevention

\section{Introduction}

In December 2019, several cases of pneumonia of an unknown etiology were reported in Wuhan, China [1]. On January 20, 2020, the Centers for Disease Control and Prevention (CDC) as well as state and local health departments began monitoring the burgeoning situation [2]. By the end of January, the World Health Organization (WHO) had declared the outbreak to be of serious concern [3]. The disease, now known as coronavirus disease 2019 (COVID-19) and caused by severe acute respiratory syndrome coronavirus 2 (SARS-CoV-2), was officially named by WHO on February 11, 2020 [4]. By March
7,2020 , the global number of reported cases had surpassed 100,000 [5].

As a novel global health threat, the scientific community has only begun to investigate the distinguishing features of COVID-19. Epidemiological and biomedical research thus far suggests the following. The incubation period ranges from 1-14 days [6]. COVID-19 is largely spread by contact with respiratory droplets from an infected individual. Symptoms most commonly include fever, fatigue, and a dry cough [6]. The Chinese Center for Disease Control and Prevention reports from mid-February indicated a case fatality rate of $2.3 \%$ and that $81 \%$ of cases were mild in nature [7]. It is understood that the case fatality rate will 
shift as more cases are identified. However, it also became clear that COVID-19 is substantially deadlier than seasonal influenza [8]. The risk of severe illness and death appears to be concentrated among older populations and those with underlying medical conditions [9].

It is unclear how long SARS-CoV-2 survives on surfaces, but estimates suggest anywhere from a few hours to several days [10]. Community spread has been reported worldwide [3], and on March 11, 2020, the WHO declared COVID-19 a pandemic [11]. Testing in the United States was delayed in late February and March, hampering case identification efforts [12]. Testing may have been hindered initially by not only a lack of tests but also out-of-pocket costs for those uninsured or underinsured [13]; on March 5, 2020, America's Health Plans indicated they would waive copays for COVID-19 testing. Containment is complicated by the fact that substantial numbers of Americans lack paid sick leave [14], and, as of March 13, 2020, public schools in densely populated urban areas such as New York continued to remain open. Projections of widespread transmission indicate that health care systems may rapidly become overwhelmed [3]. There are no specific treatments for the virus at present [9]. Concerns over COVID-19 have had a swift impact on global financial markets with potential long-term repercussions on a number of sectors [15]. As with SARS-CoV, a number of news outlets have reported a swift uptick in anti-Asian racism [16-18]. In some areas, public fears about COVID-19 have led to panic buying of supplies including personal protective equipment, reducing the availability of necessary supplies for health care workers [10].

One of the most important aspects of an effective campaign to minimize COVID-19 transmission is accurate information that is conveyed in a way that is understood by the public. Google Trends demonstrates a substantial spike in interest in COVID-19 since early February 2020 [19], and the WHO has characterized the exponential increase in information (and misinformation) about COVID-19 as an "infodemic" [20]. The CDC and WHO have steadily been posting content discoverable on the internet. Moreover, the WHO has been working with social media outlets to ensure users searching for information on COVID-19 are guided to reliable sources [21]. Despite these efforts, in novel and rapidly evolving situations, there is a high potential for misinformation and disinformation to spread through online sources [22,23]. As the second most popular social media platform after Google [24] and with over 2 billion users [25],
YouTube is a media channel that millions turn to when seeking information on COVID-19. Even videos that cover COVID-19 in a particular national context likely have a global reach. Although previous investigations have examined the content of YouTube videos on infectious diseases such as Ebola [26,27], H1N1 influenza [28,29], West Nile virus [30], and Zika virus [31], we did not identify any published studies that have investigated the content of YouTube videos related to COVID-19. This study, therefore, aimed to address this gap in current knowledge.

\section{Methods}

The sample of videos was delimited to the 100 most widely viewed YouTube videos uploaded throughout the month of January 2020. The keyword "Coronavirus" was used as the search term, which was the most widely used terminology to describe COVID-19 at that time. The videos were sorted by view count to identify the 100 most widely viewed videos (in both English, including subtitles, and Spanish). There were 7 videos excluded and replaced: 5 for irrelevance (not about the virus) and 2 because they were in a language other than English or Spanish.

Coding categories (Table 1) were created using a CDC fact sheet on COVID-19 [3,9] and prior YouTube studies on Ebola and Zika [26,31]. Content was classified into 5 categories: prevention behaviors, mortality and fear, symptoms, transmission and natural history, or other precautions. The characteristics of videos that were coded included number of views, length in minutes, language, presentation style, and source and date of upload. Three sources of upload comprised mutually exclusive and exhaustive categories: consumer, professional (MD or $\mathrm{RN}$ ), and television- or internet-based news. Author CJ coded content across all videos, and a second author (CHB) coded a randomly selected subset of 10 videos to ascertain inter-rater reliability, which was assessed using Cohen kappa and found to be excellent $(\mathrm{k}=0.971)$.

Descriptive statistics were calculated, including frequencies and percentages and, where appropriate, means and standard deviations. Differences between content covered in videos uploaded from different sources was assessed by chi-square tests using a two-sided $P$ value <.05. All analyses were performed using SPSS version 26 (IBM Corp). 
Table 1. Description of content covered in 100 widely viewed YouTube videos about coronavirus disease 2019, January 2020.

\begin{tabular}{|c|c|c|c|c|c|c|}
\hline Categories & $\begin{array}{l}\text { Total }(\mathrm{N}=100) \\
\mathrm{n}(\%)\end{array}$ & $\begin{array}{l}\text { Number of views } \\
(\mathrm{n}=125,286,561), \mathrm{n}(\%)\end{array}$ & $\begin{array}{l}\text { Consumer } \\
(\mathrm{n}=11), \mathrm{n}(\%)\end{array}$ & $\begin{array}{l}\text { Professional } \\
(\mathrm{n}=4), \mathrm{n}(\%)\end{array}$ & $\begin{array}{l}\text { News }(\mathrm{n}=85) \\
\mathrm{n}(\%)\end{array}$ & $P$ value \\
\hline \multicolumn{7}{|l|}{ Prevention behaviors } \\
\hline Hand hygiene & $26(26)$ & $33,268,243(26.55)$ & $4(36)$ & $2(50)$ & $20(24)$ & .39 \\
\hline $\begin{array}{l}\text { Avoid close contact with those who are } \\
\text { sick }\end{array}$ & $31(31)$ & $41,269,546(32.94)$ & $5(45)$ & $3(75)$ & $23(27)$ & .09 \\
\hline Stay home when ill & $29(29)$ & $42,647,990(34.04)$ & $5(45)$ & $2(50)$ & $22(26)$ & .28 \\
\hline $\begin{array}{l}\text { Cover cough/sneeze with tissue; throw } \\
\text { tissue away }\end{array}$ & $14(14)$ & $19,625,830(15.66)$ & $3(27)$ & $1(25)$ & $10(12)$ & .36 \\
\hline $\begin{array}{l}\text { Use facemask for protection if you are } \\
\text { caring for the ill }\end{array}$ & $0(0)$ & $0(0.00)$ & $0(0)$ & $0(0)$ & $0(0)$ & $\mathrm{N} / \mathrm{A}^{\mathrm{a}}$ \\
\hline $\begin{array}{l}\text { Use facemask for protecting others if } \\
\text { you are ill }\end{array}$ & $2(2)$ & $1,152,765(0.92)$ & $1(9)$ & $0(0)$ & $1(1)$ & .36 \\
\hline $\begin{array}{l}\text { Clean and disinfect highly touched ob- } \\
\text { jects and surfaces }\end{array}$ & $16(16)$ & $17,545,061(14.00)$ & $4(36)$ & $2(50)$ & $10(12)$ & .04 \\
\hline \multicolumn{7}{|l|}{ Mortality or fear } \\
\hline Mentions death & $84(84)$ & $101,216,230(80.79)$ & $9(82)$ & $4(100)$ & $71(84)$ & .49 \\
\hline Suggests anxiety or fear & $79(79)$ & $101,017,274(80.63)$ & $10(91)$ & $3(75)$ & $66(78)$ & .53 \\
\hline \multicolumn{7}{|l|}{ Symptoms } \\
\hline Coughing & $37(37)$ & $48,785,552(38.94)$ & $5(45)$ & $1(25)$ & $31(36)$ & .74 \\
\hline Shortness of breath & $26(26)$ & $36,446,095$ (29.09) & $4(36)$ & $1(25)$ & $21(25)$ & .72 \\
\hline Fever & $43(43)$ & $59,530,161(47.52)$ & $7(64)$ & $3(75)$ & $33(39)$ & .12 \\
\hline \multicolumn{7}{|l|}{ Transmission and natural history } \\
\hline Modes of transmission & $42(42)$ & $63,474,010(50.66)$ & $5(45)$ & $4(100)$ & $33(39)$ & .025 \\
\hline Incubation period & $47(47)$ & $55,706,189(44.46)$ & $7(64)$ & $3(75)$ & $37(44)$ & .23 \\
\hline Treatment & $21(21)$ & $33,676,717(26.88)$ & $2(18)$ & $1(25)$ & $18(21)$ & .96 \\
\hline \multicolumn{7}{|l|}{ Other precautions } \\
\hline Quarantine & $89(89)$ & $109,741,111(87.59)$ & $11(100)$ & $4(100)$ & $74(87)$ & .15 \\
\hline Remain indoors & $39(39)$ & $59,527,347(47.51)$ & $6(55)$ & $2(50)$ & $31(36)$ & .47 \\
\hline Restrict travel & $84(84)$ & $96,914,919(77.35)$ & $10(91)$ & $3(75)$ & $71(84)$ & .71 \\
\hline
\end{tabular}

${ }^{\mathrm{a}}$ Not applicable.

\section{Results}

At the time of data collection (January 31, 2020), the videos in the sample were viewed more than 125 million times (by March 5, 2020, these videos garnered an additional 41 million views). The mean number of views per video was $1,252,865.6$ (SD $954,752.0$ ), and the mean length was 6.4 minutes (SD 6.4 minutes; range 15 seconds to 45 minutes). Of the 100 videos, the majority $(n=85,85.0 \%)$ were uploaded by news agencies (aired on television or the internet). Most were created in English $(\mathrm{n}=72,72.0 \%)$ or with English subtitles $(\mathrm{n}=14,14.0 \%)$, but $14.0 \%(n=14)$ were in Spanish. The large majority $(n=87$, $87.0 \%)$ featured a live presenter and $13.0 \%(n=13)$ featured animation.

Fewer than one-third of the videos covered any of the seven key prevention behaviors listed on the CDC website (Table 1). Just over a quarter of the videos covered hand hygiene and less than one-fifth mentioned covering a cough or sneeze with a tissue and then discarded. Although $45.0 \%(n=45)$ mentioned using a face mask, none recommended using a face mask when caring for someone who is sick, and only 2 mentioned using a face mask if you are sick to protect others. Cleaning and disinfecting frequently touched surfaces was mentioned in less than one-fifth of the videos.

The majority of videos mentioned death, or suggested anxiety or fear. Symptoms, transmission, and natural history were covered in fewer than half of the videos. Quarantine and travel restrictions were mentioned in the majority of videos. The content covered generally did not vary by source of upload.

\section{Discussion}

The videos in the study sample were viewed over 125 million times as of January 31, 2020 (and increased by over $30 \%$ to over 165 million views by March 5, 2020), indicating the 
considerable reach of YouTube as a way to communicate with the public. Knowledge about the biology, pathophysiology, and epidemiology of COVID-19 is evolving rapidly. What we do know at this time is that personal behaviors are the best way to prevent disease transmission and COVID-19.

Accurate information and guidance about personal behavior is, therefore, one of the most important elements in mitigating the spread of COVID-19. Primary prevention of any disease relies on two components: reducing exposure and reducing susceptibility. Given that no vaccine is currently available to reduce susceptibility, the most effective way to prevent disease transmission and prevent illness is by preventing exposure. COVID-19 is a propagated epidemic (spreads from person-to-person) and is thought to be transmitted through both direct and indirect contact [32]. The CDC recommends behaviors to protect individuals by reducing exposure: proper hand hygiene (including avoiding touching one's nose, mouth, and eyes with unwashed hands) and avoiding close contact, not only with people who are sick, but also through social distancing (especially for those at higher risk, namely, older adults and those with chronic illnesses). The CDC further recommends behaviors to protect others: staying home when sick (except to receive medical care); covering one's sneeze or cough with a tissue (or inside of elbow), then discarding the tissue in trash, immediately followed by proper hand hygiene; wearing a mask if ill when around others or caring for someone who is sick; and cleaning and disenfecting frequently touched surfaces [33]. These recommendations may be difficult to understand, especially for the considerable proportion of the public with low levels of reading literacy. Video presentation is a potentially useful alternative for communicating key information to the public. We found that fewer than one-third of the most widely viewed YouTube videos covered any of these behavioral recommendations, which we believe represents an important missed opportunity for disease prevention.

In contrast, the majority of the 100 videos mentioned number of deaths or estimated mortality rates, or suggested fear and anxiety, and these videos were collectively viewed over 100 million times. Communications that increase fear and anxiety may prompt preventive actions, but may also lead to maladaptive, socially irresponsible behaviors such as hoarding medical supplies, hygienic supplies, and food items and making unnecessary visits to physicians and emergency rooms [34]. Accurate information must be conveyed by designated spokespersons who can promote primary and secondary prevention behaviors, model rational thinking, and allay unrealistic or excessive fears about the future [35]. The most widely viewed YouTube videos on COVID-19 do not achieve these aims. Thus, we conclude that in addition to reducing risk of exposure through recommended behaviors, it is clear that consumers must also become critical evaluators of disseminated information about COVID-19 found on YouTube.

This study extends awareness about the content of widely viewed videos on YouTube during the early days of the COVID-19 outbreak, but there are limitations that must be mentioned. Recommendations are being updated frequently and more recent YouTube videos may cover preventive behaviors to a greater extent. Nevertheless, the number of views garnered by videos in our sample continued to grow. As with all cross-sectional studies, the use of one data collection point is limiting. As the state of YouTube is in a state of fluctuation, thus, the videos with the most views may change over time. It is also possible that, as more information is learned about the disease, common search terms and content will evolve, despite older videos remaining online.

It is often not possible to determine the geographic location of YouTube posters. With over 2 billion users worldwide, many users likely watch videos regardless of the national origin of posters. Given this, we cannot make claims about the regionality or lack thereof of YouTube videos on COVID-19. Nevertheless, it is fair to assert that the Spanish and English language videos on COVID-19 in this sample could be reaching viewers around the world. Additionally, the prevention behaviors noted in this study could be applicable worldwide. In addition, our sample of videos was small, and 100 was an arbitrary cut point for inclusion. Further, there are issues with the impermanence of video content in that highly viewed videos may contain outdated information regardless of the accuracy of the information when the videos were produced. In addition to efforts to promote authoritative information, YouTube could benefit from clearly demarcating the most current, valid information. This would be especially useful in instances such as the COVID-19 pandemic, where information is changing rapidly. Although this study represents this sample of videos at a point in time, it offers insight about the nature of content that is and is not covered, and suggests opportunities to convey information to mitigate the spread of COVID-19 and help people make informed decisions about caring for and protecting themselves and their families.

\section{Conflicts of Interest}

None declared.

\section{References}

1. Arabi YM, Murthy S, Webb S. COVID-19: a novel coronavirus and a novel challenge for critical care. Intensive Care Med 2020 Mar 03 [FREE Full text] [doi: 10.1007/s00134-020-05955-1] [Medline: $\underline{\text { 32125458] }}$

2. Burke RM, Midgley CM, Dratch A, Fenstersheib M, Haupt T, Holshue M, et al. Active monitoring of persons exposed to patients with confirmed COVID-19 - United States, January-February 2020. MMWR Morb Mortal Wkly Rep 2020 Mar 06;69(9):245-246 [FREE Full text] [doi: 10.15585/mmwr.mm6909e1] [Medline: 32134909]

3. Centers for Disease Control and Prevention. Coronavirus disease 2019 (COVID-19) situation summary URL: https://www. cdc.gov/coronavirus/2019-ncov/summary.html [accessed 2020-03-08] 
4. Wu Y, Chen C, Chan Y. The outbreak of COVID-19: an overview. J Chin Med Assoc 2020 Mar;83(3):217-220. [doi: 10.1097/JCMA.0000000000000270] [Medline: 32134861]

5. World Health Organization. Coronavirus disease 2019 (COVID-19) situation report - 47 URL: https://www.who.int/docs/ default-source/coronaviruse/situation-reports/20200307-sitrep-47-covid-19.pdf?sfvrsn=27c364a4_2 [accessed 2020-03-08]

6. World Health Organization. Q\&A on coronavirus (COVD-19) URL: https://www.who.int/news-room/q-a-detail/ q-a-coronaviruses [accessed 2020-03-08]

7. Fisher D, Heymann D. Q\&A: The novel coronavirus outbreak causing COVID-19. BMC Med 2020 Feb 28;18(1):57 [FREE Full text] [doi: 10.1186/s12916-020-01533-w] [Medline: $\underline{\text { 32106852] }}$

8. Gates B. Responding to Covid-19 — a once-in-a-century pandemic? N Engl J Med 2020 Feb 28. [doi: 10.1056/nejmp2003762]

9. Centers for Disease Control and Prevention. Coronavirus disease 2019 (COVID-19): prevention \& treatment 2020 URL: https://www.cdc.gov/coronavirus/2019-ncov/prevent-getting-sick/prevention.html [accessed 2020-03-08]

10. World H. World Health Organization. 2020. Shortage of personal protective equipment endangering heatlh workers worldwide URL: https://www.who.int/news-room/detail/03-03-2020-shortage-of-personal-protective-equipmentendangering-health-workers-worldwide [accessed 2020-03-08]

11. World Health Organization. 2020. Rolling updates on coronvavirus disease (COVID-19) URL: https://www.who.int/ emergencies/diseases/novel-coronavirus-2019/events-as-they-happen [accessed 2020-03-13]

12. Rabin R, Sheikh K, Thomas K. As coronavirus numbers rise, CDC testing comes under fire. New York Times 2020 Mar 02 [FREE Full text]

13. Abrams A. Time USA. 2020 Mar 04. America's health system will likely make the coronavirus outbreak worse URL: https:/ /time.com/5794672/health-insurance-deductibles-coronavirus/ [accessed 2020-03-08]

14. Fields S. Marketplace. 2020 Mar 06. COVID-19 response complicated by inequities in health insurance, sick leave URL: https://www.marketplace.org/2020/03/06/covid-19-response-complicated-by-inequities-in-health-insurance-sick-leave/ [accessed 2020-03-08]

15. David Y, Stanley R, Matt P, Niraj C, Tiffany H, Sapna M. Stocks plunge again on coronavirus fears. The New York Times 2020 Mar 05 [FREE Full text]

16. Escobar N. When xenophobia spreads like a virus. NPR 2020 Mar 04 [FREE Full text]

17. Haynes S. Time USA. 2020 Mar 06. As coronavirus spreads, so does xenophobia and anti-Asian racism URL: https://time. com/5797836/coronavirus-racism-stereotypes-attacks/ [accessed 2020-03-08]

18. Pan D. Fears of coronavirus fuel anti-Chinese racism. Boston Globe 2020 Jan 30 [FREE Full text]

19. Google Trends. COVID-19 URL: https://trends.google.com/trends/explore?q=COVID-19\&geo=US [accessed 2020-03-08]

20. Zarocostas J. How to fight an infodemic. The Lancet 2020 Feb;395(10225):676. [doi: 10.1016/s0140-6736(20)30461-x]

21. Duffy C. How health officials and social media are teaming up to fight the coronavirus "infodemic". CNN Business 2020 Mar 01 [FREE Full text]

22. Homeland Security. 2018 Mar. Countering false information on social media in disasters and emergencies URL: https:/ /www.dhs.gov/sites/default/files/publications/SMWG Countering-False-Info-Social-Media-Disasters-Emergencies Mar2018-508.pdf

23. World Health Organization. 2020 Mar 05. Coronavirus disease 2019 (COVID-19) situation report - 45 URL: https://www. who.int/docs/default-source/coronaviruse/situation-reports/20200305-sitrep-45-covid-19.pdf?sfvrsn=ed2ba78b 2 [accessed 2020-03-08]

24. Alexa. The top 500 sites on the web URL: https://www.alexa.com/topsites [accessed 2020-03-08]

25. YouTube. YouTube for press URL: https://www.youtube.com/about/press/ [accessed 2020-03-08]

26. Basch CH, Basch CE, Ruggles KV, Hammond R. Coverage of the Ebola virus disease epidemic on YouTube. Disaster Med Public Health Prep 2015 Oct;9(5):531-535. [doi: 10.1017/dmp.2015.77] [Medline: 26088275]

27. Nagpal SJS, Karimianpour A, Mukhija D, Mohan D, Brateanu A. YouTube videos as a source of medical information during the Ebola hemorrhagic fever epidemic. Springerplus 2015 Aug 28;4(1):457 [FREE Full text] [doi:

10.1186/s40064-015-1251-9] [Medline: 26322263]

28. Luoma-aho V, Tirkkonen P, Vos M. Monitoring the issue arenas of the swine - flu discussion. JCOM 2013 Jul 26;17(3):239-251. [doi: 10.1108/jcom-11-2010-0069]

29. Walton L, Seitz H, Ragsdale K. Strategic use of YouTube during a national public health crisis: the CDC's response to the 2009 H1N1 flue epidemic. Case Studies in Strategic Communication 2012;1:25-37 [FREE Full text]

30. Dubey D, Amritphale A, Sawhney A, Dubey D, Srivastav N. Analysis of YouTube as a source of information for West Nile virus infection. Clin Med Res 2014 Dec;12(3-4):129-132 [FREE Full text] [doi: 10.3121/cmr.2013.1194] [Medline: 24573700]

31. Basch CH, Fung IC, Hammond RN, Blankenship EB, Tse ZTH, Fu K, et al. Zika virus on YouTube: an analysis of English-language video content by source. J Prev Med Public Health 2017 Mar;50(2):133-140 [FREE Full text] [doi: 10.3961/jpmph.16.107] [Medline: 28372356]

32. Centers for Disease Control and Prevention. 2020. Coronavirus disease 2019 (COVID-19): how coronavirus spreads URL: https://www.cdc.gov/coronavirus/2019-ncov/prepare/transmission.html?CDC_AA_refVal=https\%3A\%2F\%2Fwww.cdc. gov\%2Fcoronavirus\%2F2019-ncov\%2Fabout\%2Ftransmission.html [accessed 2020-03-13] 
33. Centers for Disease Control and Prevention. Coronavirus disease 2019 (COVID-19): stop the spread of rumors URL: https:/ /www.cdc.gov/coronavirus/2019-ncov/symptoms-testing/share-facts.html?CDC AA refVal=https\%3A\%2F\%2Fwww.cdc. gov\%2Fcoronavirus\%2F2019-ncov\%2Fabout\%2Fshare-facts.html [accessed 2020-03-13]

34. Wheaton MG, Abramowitz JS, Berman NC, Fabricant LE, Olatunji BO. Psychological predictors of anxiety in response to the H1N1 (swine flu) pandemic. Cogn Ther Res 2011 Feb 22;36(3):210-218. [doi: 10.1007/s10608-011-9353-3]

35. Levin PJ, Gebbie EN, Qureshi K. Can the health-care system meet the challenge of pandemic flu? Planning, ethical, and workforce considerations. Public Health Rep 2007;122(5):573-578 [FREE Full text] [doi: 10.1177/003335490712200503] [Medline: 17877303]

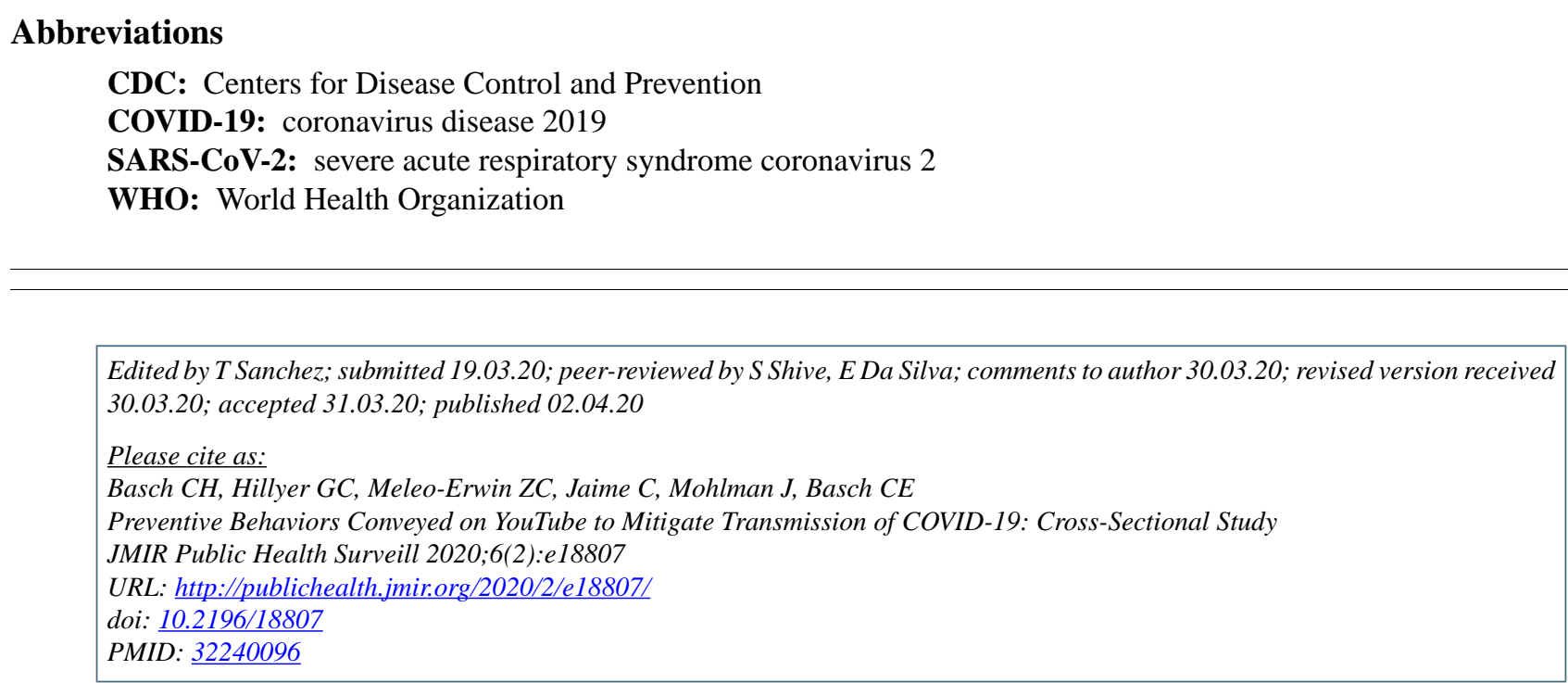

(C) Corey H Hannah Basch, Grace C Hillyer, Zoe C Meleo-Erwin, Christie Jaime, Jan Mohlman, Charles E Basch. Originally published in JMIR Public Health and Surveillance (http://publichealth.jmir.org), 02.04.2020. This is an open-access article distributed under the terms of the Creative Commons Attribution License (https://creativecommons.org/licenses/by/4.0/), which permits unrestricted use, distribution, and reproduction in any medium, provided the original work, first published in JMIR Public Health and Surveillance, is properly cited. The complete bibliographic information, a link to the original publication on http://publichealth.jmir.org, as well as this copyright and license information must be included. 